\title{
The Effect of E-learning Based Schoology on the Learning Outcomes and Problem Solving Skills in Chemistry
}

\author{
Syahmani, Rilia Iriani, Nur Aisyah \\ Chemistry Education Study Program, Faculty of Teacher Training Education \\ Universitas Lambung Mangkurat \\ Banjarmasin, Indonesia \\ syahmani_kimia@ulm.ac.id
}

\begin{abstract}
This study aims to determine the differences of cognitive learning outcome and problem solving skills between classes taught by using problem solving learning model through Schoology and problem solving Polya model in solubility and Constant Solubility Product material. This quasi-experimental research employed the non-equivalent control group design and was conducted at class XI-MIPA of SMAN 8 Banjarmasin. This research used a purposive sampling technique. The data were collected by using test and non-test instrument. They were analyzed using a t-test, Wilcoxon signed rank test and descriptive analysis. The result of this study showed that there are differences in cognitive learning and problem solving skills significantly between students who learned by using problemsolving learning model through Schoology and problem solving Polya model. The cognitive learning achievement of students who learned by using problem solving learning model through schoology was better than those who learned by using problem solving Polya model.
\end{abstract}

Keywords-Cognitive Learning Achievement; Problem Solving Skill; Schoology; Solubility and Constant Solubility Product.

\section{INTRODUCTION}

The 21st century is known as the era of information technology and globalization. Information technology and education are two things that are growing very rapidly and cannot be separated in this modern era. Technological development is expected to support and improve the quality of education in schools.

Education in the 21st century relates to new problems in the real world. Problem solving based learning approaches relate to the use of intelligence from individuals who are in a group of people or the environment to solve problems that are meaningful, relevant, and contextual [1]. In this modern era, we need human resources which are not only intelligent but also have the ability to solve problems. Education, especially science, is a factor for students to learn to think to solve problems in learning so that they can apply these problemsolving abilities in everyday life.

As it is the case for science education in general, the existing body of chemistry education research mainly highlights problems and challenges [2]. Students' attitudes and interest in chemistry are often reported to be negative [3][4], and international projects such as PISA indicates that students' knowledge of chemistry content is declining [5][6]. Moreover, chemistry is perceived to be difficult [7][8] and abstract [8]. Students' cognitive learning outcomes on solubility and constant solubility product material at SMAN 8 Banjarmasin can be seen from the national exam results show still fairly low at only $24.49 \%$. In the level of Banjarmasin City, South Kalimantan Province, and national respectively were: $25.49 \%$, $27.63 \%$, and $46.66 \%$ [9]. Based on these data it can be seen that students learning outcome results are still low so that learning improvements in that material are needed.

Various explanations for these perceptions have been suggested: [10] claim that students focus excessively on memorizing facts and formulae rather than understanding concepts and developing problem solving skills, while [11] relate students' difficulties in chemistry to their limited informal everyday experiences with the subject. Consequently, different strategies have been developed to connect chemistry to higher order thinking and interesting and relevant everyday life areas, e.g., problem solving approaches.

The alternative solution for improving students learning outcomes and problem solving skills in chemistry is problem solving learning models. Problem solving ability is the core of problem based learning that trains students to solve problems to be applied in life [12], and examines problem solving during meaningful tasks for the promotion of higher order thinking and the cognitive aspects of students' learning [13]. Problem solving is a research area that has been studied in chemistry education for several years and is unquestionably important [14] [15]

Problem solving ability is one of the important abilities that students must possess. There are four phases to solve the problem. First, we have to understand the problem. Second, devise a plan to see how the various items are connected, how the unknown is linked to the data, to obtain the idea of the solution. Third, carry out the plan. And then, look back at the complete solution, we review and discuss it [16].

Schoology is a learning management system that provides facilities to teachers and students to interact in a learning environment through online social networks [17]. Through the problem solving learning model, students construct concepts learned independently with the help of various learning sources 
obtained online so that students are motivated to learn [18]. There was an increase in learning outcomes of students using schoology assisted learning [19]. The learning that utilizes technology in the form of the web can improve students' problem solving abilities. Based on the research, it was found that there was an increase in students' problem solving ability after being given assignments through learning that combined face-to-face learning with online learning [20].

The ability to understand the relationship among concepts, maturity in reasoning, and active involvement in learning is a necessary part of solving problems. Through learning using a Problem solving, learning model through Schoology is expected to have a positive influence on students' ability to solve problems. The study would determine the differences in cognitive learning outcomes and problem solving skills between the classes taught by using Problem SolvingSchoology and Problem Solving Polya in solubility and constant solubility product material.

\section{METHOD}

\section{A. Research Design Selecting}

This study used the quasi-experimental method with the non-equivalent control group design conducted at class XIMIPA of SMAN 8 Banjarmasin Academic year 2017/2018.

\section{B. Sampling Technique}

The sampling technique used in this study was a purposive sampling [21]. The samples chosen were the XI-MIPA 4 class as an experimental group that consists of 29 students and XIMIPA 3 class that consists of 25 students as a control group.

\section{Instrument and Data Analysis}

The instruments in this study were test and non-test. The tests function to measure the students' cognitive achievement and problem solving skills. The cognitive achievement test was in the multiple choice form, and problem solving skills test was in the essay form. The indicators of problem solving skills used in essay form were understanding the problem, devising a plan, carrying out the plan, and looking back. The judgment of five validators determines the validity of the instrument. The validators were four chemistry lecturers of FKIP ULM Banjarmasin and one chemistry teacher from SMAN 8 Banjarmasin. Based on a calculation using the equations CVR (Content Validity Ratio), the obtained result was $=1$. This result indicates that the instrument of cognitive achievement test and problem solving skills test were valid [22].

The valid instruments were subsequently tested before being used in research to determine the level of reliability. Based on SPPS 23 version calculations by the Cronbach alpha formula, the obtained value of the degree of cognitive achievement test $=0.780$ and problem solving skills test $=$ 0.680 . If the reliability value is more than 0.6 , it indicates that the instruments are reliable [23].

Data were analyzed using descriptive and inferential analysis. The inferential analysis used in this research was a ttest. T-test term refers to the test of normality and homogeneity of data. This test aims to determine whether there is a difference is generated between the control group and the experimental group. The attitude data was analyzed by Wilcoxon signed rank test.

\section{RESULTS AND DISCUSSION}

\section{A. Result}

\section{1) Student Learning Achievement}

The students were given a pre-test before learning to know their initial cognitive learning achievement. After learning process ended, the students were given a post-test to determine their cognitive learning achievement. Data of pre-test and posttest of cognitive learning achievements is displayed in Table 1.

TABLE I. PRETEST And Posttest Results OF Students LEARNING ACHIEVEMENT

\begin{tabular}{|l|l|l|l|l|l|}
\hline \multirow{2}{*}{$\begin{array}{c}\text { Learning } \\
\text { Result } \\
(\%)\end{array}$} & \multirow{2}{*}{ Category } & \multicolumn{2}{c|}{$\begin{array}{c}\text { Frequency } \\
\text { Experiment Class }\end{array}$} & \multicolumn{2}{c|}{$\begin{array}{c}\text { Frequency } \\
\text { Control Class }\end{array}$} \\
\cline { 3 - 6 } & & Pretest & Posttest & Pretest & Posttest \\
\hline $91-100$ & Very good & 0 & 6 & 0 & 3 \\
\hline $83-90$ & Good & 0 & 8 & 0 & 2 \\
\hline $75-82$ & Enough & 0 & 8 & 0 & 9 \\
\hline$<75$ & Less & 29 & 7 & 25 & 11 \\
\hline Total & 29 & 29 & 25 & 25 \\
\hline
\end{tabular}

Based on the data in Table 1, we can calculate the average value of a class than can be seen in Table 2 .

TABLE II. AVERAGE VALUE OF STUDENTS' LEARNING ACHIEVEMENT

\begin{tabular}{|c|c|c|c|c|}
\hline \multirow{2}{*}{ Value } & \multicolumn{2}{|c|}{ Experiment Class } & \multicolumn{2}{|c|}{ Control Class } \\
\hline & Pretest & Posttest & Pretest & Posttest \\
\hline Lowest & 10 & 60 & 10 & 60 \\
\hline Highest & 50 & 100 & 50 & 100 \\
\hline Average & 32.07 & 84.14 & 31.60 & 76.80 \\
\hline
\end{tabular}

Data of cognitive learning results of the two subsequent classes are categorized based on the applicable standard of completeness. The data from Standard of Minimum Learning Mastery (SKBM) can be seen in Table 3.

TABLE III. STANDARD MASTERY OF LEARNING

\begin{tabular}{|l|l|l|l|}
\hline \multicolumn{1}{|c|}{ Value } & \multicolumn{1}{|c|}{$\begin{array}{c}\text { Experiment } \\
\text { Class }\end{array}$} & \multicolumn{1}{c|}{$\begin{array}{c}\text { Control } \\
\text { Class }\end{array}$} & \multicolumn{1}{|c|}{ Information } \\
\hline$<75$ & 7 & 11 & Not Complete \\
\hline$\geq 75$ & 22 & 14 & Completed \\
\hline Class Completeness $(\%)$ & 75.86 & Completed \\
\hline
\end{tabular}

Data of cognitive achievement obtained from the pre-test and post-test data is then processed into $\mathrm{N}$-gain to determine the extent to students in each class that has increased cognitive achievement after participating in the learning on the solubility and constant solubility product material. The average $\mathrm{N}$-gain obtained and interpreted by the criteria proposed by [24] as shown in Table 4. 
TABLE IV. INTERPRETATION OF N-GAIN STUDENTS' LEARNING ACHIEVEMENT

\begin{tabular}{|l|l|l|}
\hline \multicolumn{1}{|c|}{ Class } & \multicolumn{1}{|c|}{ Average N-gain } & \multicolumn{1}{c|}{ Category } \\
\hline Experiment & 0.77 & High \\
\hline Control & 0.66 & Medium \\
\hline
\end{tabular}

Based on the calculation of normality and homogeneity test of pre-test and post-test data, the data on students' learning achievement was normal and homogenous. Therefore, the hypothesis analysis can use t-test.

The t-test was used to determine the difference of student's learning achievements between experiment class and control class. The t-test result is seen in Table 5 .

TABLE V. The Results of T-TeSt Students' Cognitive LEARNing

\begin{tabular}{|c|c|c|c|c|c|c|c|}
\hline Class & $\mathbf{N}$ & Df & $\overline{\mathbf{X}}$ & SD2 & $t-$ count & $t_{-}$table & Information \\
\hline Experiment & 29 & \multirow{2}{*}{52} & 84.14 & 132.27 & \multirow{2}{*}{2.190} & \multirow{2}{*}{2.007} & \multirow{2}{*}{$\begin{array}{l}\mathrm{H}_{0} \text { rejected } \\
\text { There is } \\
\text { significant } \\
\text { difference }\end{array}$} \\
\hline Control & 25 & & 76.80 & 156.00 & & & \\
\hline
\end{tabular}

Based on SPPS 23 version, calculations were done by the related-samples Wilcoxon signed rank test. The test was used to determine the difference of student's learning attitude in curiosity between pre-test and post-test. The test result is in Table 6.

TABLE VI. The Result of Wilcoxon Test Students' ATtitude IN CURIOSITY

\begin{tabular}{|c|c|l|l|l|l|}
\hline Test & N & $\begin{array}{c}\text { Standard } \\
\text { Error }\end{array}$ & $\begin{array}{l}\text { Standardized } \\
\text { Test Ststistic }\end{array}$ & Sig. & Information \\
\cline { 1 - 5 } Pre- & 29 & 15.900 & 3.300 & 0.001 & $\begin{array}{l}\mathrm{H}_{0} \text { rejected } \\
\text { test } \\
\text { significant is } \\
\text { difference }\end{array}$ \\
\hline $\begin{array}{c}\text { Post- } \\
\text { test }\end{array}$ & 2 & & & \\
\hline
\end{tabular}

This result is based on SPPS 23 version calculations by the related-samples Wilcoxon signed rank test. The test was used to determine the difference of student's learning attitude in responsibility between pre-test and post-test. The test result is shown in Table 7.

TABLE VII. The Result OF Wilcoxon TeSt StUdents’ ATtitude IN RESPONSIBILITY

\begin{tabular}{|c|l|l|l|l|l|}
\hline Test & N & $\begin{array}{c}\text { Standard } \\
\text { Error }\end{array}$ & $\begin{array}{l}\text { Standardized } \\
\text { Test Statistic }\end{array}$ & Sig. & Information \\
\cline { 1 - 5 } Pre-test & & 10.290 & 3.207 & 0.001 & $\begin{array}{l}\mathrm{H}_{0} \text { rejected } \\
\text { There is } \\
\text { significant } \\
\text { difference }\end{array}$ \\
\hline
\end{tabular}

The result is based on SPPS 23 version calculations by the related-samples Wilcoxon signed rank test. The test was used to determine the difference of student's learning attitude between experiment class and control class. The test result can be seen in Table 8 .
TABLE VIII. The Result of The Wilcoxon TeSt Students’ Attitude

\begin{tabular}{|l|l|l|l|l|l|}
\hline Class & N & $\begin{array}{c}\text { Standard } \\
\text { Error }\end{array}$ & $\begin{array}{l}\text { Standardized } \\
\text { Test Statistic }\end{array}$ & Sig. & Information \\
\cline { 1 - 2 } Experiment & 29 & 30.655 & 0.979 & 0.328 & $\begin{array}{l}\text { H0 retain } \\
\text { There is no } \\
\text { significant } \\
\text { difference }\end{array}$ \\
\hline Control & 25 & &
\end{tabular}

\section{2) Problem Solving Skills of Students}

Students were given a pre-test before learning to know their initial problem solving skill. After the learning process ends, the students are given a post-test to determine their problem solving skill. Data of pre-test and post-test of problem solving skill can be seen in Table 9.

TABLE IX. Pretest and PostTest of Problem Solving SKILL

\begin{tabular}{|l|l|l|l|l|l|}
\hline \multirow{2}{*}{ Value } & \multirow{2}{*}{ Category } & \multicolumn{2}{c|}{$\begin{array}{c}\text { Frequency } \\
\text { Experiment Class }\end{array}$} & \multicolumn{2}{c|}{$\begin{array}{c}\text { Frequency } \\
\text { Control Class }\end{array}$} \\
\cline { 3 - 6 } & $\begin{array}{c}\text { Pre- } \\
\text { test }\end{array}$ & $\begin{array}{c}\text { Post- } \\
\text { test }\end{array}$ & \multicolumn{2}{|c|}{ Pre-test } & Post-test \\
\hline $\begin{array}{l}81- \\
100\end{array}$ & $\begin{array}{l}\text { Developing } \\
\text { very well }\end{array}$ & 0 & 10 & 0 & 3 \\
\hline $61-80$ & $\begin{array}{l}\text { Already well } \\
\text { developed }\end{array}$ & 0 & 9 & 0 & 10 \\
\hline $41-60$ & Developed & 0 & 9 & 0 & 9 \\
\hline $21-40$ & $\begin{array}{l}\text { Already } \\
\text { developed }\end{array}$ & 0 & 1 & 0 & 3 \\
\hline $0-20$ & Undeveloped & 29 & 0 & 25 & 0 \\
\hline Total & & 29 & 29 & 25 & 25 \\
\hline
\end{tabular}

Based on the data in Table 9, we can calculate the average value of a class than is seen in Table 10.

TABle X. Average VAlue of Problem Solving SKiLl

\begin{tabular}{|l|l|l|l|l|}
\hline \multirow{2}{*}{ Value } & \multicolumn{2}{|c|}{ Experiment Class } & \multicolumn{2}{c|}{ Control Class } \\
\cline { 2 - 5 } & \multicolumn{1}{|c|}{ Pre-test } & \multicolumn{1}{c|}{ Post-test } & \multicolumn{1}{c|}{ Pre-test } & Post-test \\
\hline Lowest & 4.44 & 40.00 & 1.11 & 37.78 \\
\hline Highest & 17.78 & 91.11 & 18.89 & 88.89 \\
\hline Average & 10.96 & 69.81 & 8.98 & 60.49 \\
\hline
\end{tabular}

Overall, the percentage of post-test classification at each indicator of problem solving skill of experimental classes and control classes are shown in Figure 1.

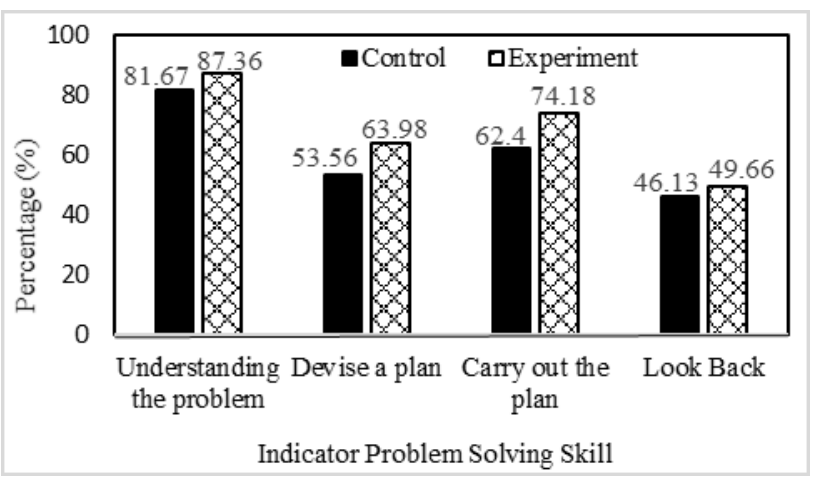

Fig. 1. Percentage of the average results of the students' problem solving skill on every indicator of experimental class and control class 
Data of problem solving skill obtained from the pre-test and post-test data is then processed into $\mathrm{N}$-gain to determine the extent to students in each class that has increased problem solving skill after participating in the learning on the solubility and constant solubility product material. The average $\mathrm{N}$-gain obtained and interpreted in Table 11.

TABLE XI. INTERPRETATION OF N-GAIN STUDENT'S PROBLEM SOLVING SKILL

\begin{tabular}{|l|l|l|}
\hline \multicolumn{1}{|c|}{ Class } & \multicolumn{1}{c|}{ Average N-gain } & \multicolumn{1}{c|}{ Category } \\
\hline Experiment & 0.68 & Medium \\
\hline Control & 0.60 & Medium \\
\hline
\end{tabular}

Based on the calculation of normality and homogeneity test of pre-test and post-test data, the data on students' problem solving was normal and homogeny. So, analysis of the hypothesis can use the t-test.

The t-test was used to determine the difference of student's problem solving between experiment class and control class. The t-test result is displayed in Table 12.

TABlE XII. The Result OF T-TESt Students’ Problem Solving SKILL

\begin{tabular}{|c|c|c|c|c|c|c|c|}
\hline Class & $\mathbf{N}$ & Df & $\overline{\mathbf{X}}$ & SD $^{2}$ & t- count & t-table & Information \\
\hline Experiment & 29 & \multirow{2}{*}{52} & 69.81 & 219.77 & \multirow{2}{*}{2.248} & \multirow{2}{*}{2.007} & \multirow{2}{*}{$\begin{array}{l}\mathrm{H}_{0} \text { rejected } \\
\text { There is } \\
\text { significant } \\
\text { difference }\end{array}$} \\
\hline Control & 25 & & 60.49 & 224.11 & & & \\
\hline
\end{tabular}

\section{B. Discussion}

\section{1) Student Learning Achievement}

Cognitive achievement tests were performed twice: before learning (pre-test) and after learning (post-test). Based on the result of the homogeneity test, pre-test results of students in the experimental class and control indicate as homogeneous. Also, based on the results of inferential analysis using t-test on the pre-test, the students in both classes have no significant differences in cognitive achievements between experimental and control class.

Based on the test result of inferential analysis using a t-test, there is a significant difference in the result between the two classes after being given the treatment. The difference is due to the learning achievement of the experimental class using Problem solving learning model through Schoology and learning achievement in class control using Problem Solving Polya. Problem solving learning model through Schoology can create a conductive atmosphere of learning. This result is because the students are more active, more likely to be enthusiastic about accomplishing the given tasks, and of course, it will affect their learning achievements.

Comparison of improvement of students' cognitive learning achievements in the experimental class and control one can be known by determining the value of $\mathrm{N}$-gain in both classes of the pre-test and post-test for each class. The research showed the average value of the two classes of $\mathrm{N}$-gain, then they are compared to determine which class whose cognitive learning achievement is better. The average of $\mathrm{N}$-gain of the experimental class is 0.77 , and it is included in the high category, while the average of $\mathrm{N}$-gain of the control class is 0.66 and it is included in the medium category. It can be said that the Problem solving learning model through Schoology is more effective in improving the students' cognitive learning achievements in this research. The percentage of completeness of the experimental class learning outcomes was $75.86 \%$. These results indicate that the experimental class has a higher achievement than the control class.

The result of this study is in line with the previous study which stated that the learning model with web-assisted could improve learning outcomes and student perceptions. The findings obtained are because students who use these learning can reduce the risk of memory loss and can increase the value of the examination [25]. Also, the other study shows an increase in learning outcomes of students by using Schoology [19].

Attitude achievement is the impact of the accompaniment of the results of a learning process as a result of the creation of a learning atmosphere experienced by students. Students' curiosity and responsibility increase significantly before and after learning. The attitude of students has developed in a good category so that more steady habituation of the internalization of aspects of attitude requires a longer and more continuous time [26] [27]. In problem solving, students will be accustomed to understand the problem, make a plan before doing something, monitor, and evaluate all their actions so that it will form a competent and good character human resources.

Comparison of the improvement of students' attitude learning achievements in the experimental class and control class does not have a significant difference. This result indicates that the two learning models applied to the experimental and control classes provide almost the same (no different) improvement.

\section{2) Problem Solving Skills of Students}

The description of the four stages problem solving Polya Model in the classroom is as follows:

- Understanding the problems: Knowing what is known and unknown, and what requirements are known. Students are familiarized to write what is known and what is asked in the problem, so they can think about the requirements needed and know which direction to go.

- Devising the plan: In this stage, students find the relations between data and the asked one or the proven one. They choose the most suitable theorem or concept and determine the most appropriate way to solve the problem. Students are familiarized to write down the needed formula or theory which related to the problem.

- Carrying out the plan: Students provide the computation part of the problem or maybe the solution. They may use facts, formula, theorems or postulates to validate their answer. Students check each step and prove that the steps are correct. 
- Looking back: Students re-check the obtained result by comparing the obtained answer with the problem and write down the conclusion of the asked question.

Problem solving skills tests are performed twice: before learning (pre-test) and after learning (post-test). All the students in the experimental and the control classes still have undeveloped problem solving skills. Therefore, the students in both classes have equal problem solving skills. The data of $t-$ test in pre-test results show that there is no difference in the test problem solving skills in the experimental class compare to the control class. Based on the inferential analysis using t-test on the post-test data from experimental and control classes, there is a significant difference in the test result. The experimental class students are better than the control class students.

The difference of problem solving skills results between the two classes is because the experimental class was taught using the Problem solving learning model through Schoology while the control class was taught using the model of Problem Solving Polya. Problem Solving-Schoology derives by a constructivist theory which states learning is the process of formation (construction) of knowledge by students themselves. Meanwhile, Piaget argued that knowledge is a human creation constructed from his/her experience, the process of formation runs continuously, and every time there is a reconstruction because there is a new understanding [28].

Schoology is online learning, classroom management, and social networking platform that attempts to improve learning through better communication, collaboration, and increased access to curriculum and supplemental content [29]. Through Schoology, students can download material that has been uploaded by the teacher in Schoology. Also, Schoology provided learning videos to attract and facilitate students in independent learning. Examples of questions that will help students in forming knowledge and understanding the material as well as examples of problem solving problems that will stimulate students to have discussions are presented in Schoology. In addition to being given examples of questions, in the material, questions that must be tried by students are provided. These features can facilitate students in learning independently and also help students to become more enthusiastic in participating in learning because so far most students feel saturated and bored with material that is always presented through textbooks. It can develop students' knowledge and students' problem solving abilities.

When implementing learning using the Problem SolvingSchoology model, students are given learning materials that have been designed to train problem solving skills. Learners can express questions, opinions, and ideas clearly according to [30] study that online learning of students is free to learn subject matter independently by utilizing learning resources available online and sharing source files with other students.

This schoology-assisted learning enables students to gain knowledge and investigate problems through the internet so that it will form a learning experience that is enjoyable for students. Based on the meaningful learning theory by Ausubel, to form meaningful new knowledge, prior knowledge needs to be activated by the introduction of material given through schoology as basic knowledge for students [31].
When the students solve the problem, they are allowed to gain experience using their knowledge and skills to solve nonroutine problems, which is more directed to process problems [32]. The implementation of problem solving learning model through Schoology would make students get a pleasant experience by conducting investigations and discussions online which can improve students' knowledge and problem solving skills. Through learning with pleasant problem solving students will remember the lesson better [33]. In addition, through the learning model of problem solving students can independently construct concepts learned with various learning resources obtained online so that they are motivated to learn [18].

Through the Problem solving learning model through Schoology, students are trained and given the freedom to construct the knowledge acquired by themselves [31]. It also causes differences in the category of development of students' problem solving abilities due to differences in learning independence built by students themselves which will be discussed in the analysis of problem solving abilities.

Overall, the students have improved problem solving skills on each indicator. The results of problem solving skills test indicate that the highest percentage indicators achieved are an indicator of understanding the problem and carry out the plan. The lowest percentage indicators achieved is devised a plan and look back. It is because students are not used to solve problems in sequence yet. Students are accustomed to working on problems directly to the action, not to careful planning first. This result is also supported by [34] that the main obstacle in the application of the problem solving skills by Polya is that students are not used to solving the problems using Polya stages, especially regarding making plans and checking again. The real problem-solving ability lies in the idea of developing a solution plan. So at this stage, it is necessary for students to think critically. At the stage of implementing the solving plan, students will explore all the concepts and procedures that have been learned so that they can solve problems correctly [16]. It is in line with the research that the indicators achieved by students with a high percentage are understanding the problem and carry out the plan, while the lowest indicator is look back and devise a plan [35].

By training and familiarizing students in completing a problem solving at the time of learning, of course, students' problem solving abilities will develop optimally. By presenting a problem to students will make students become motivated to find answers and actively investigate the subject to fulfil their curiosity. There is a problem of helping students learn a set of concepts and ideas and with group discussions will give students the experience of solving problems. It is this experience that activates their problem solving abilities so that their abilities develop [36].

Problem solving model can be combined with e-learning which aims to cover the shortcomings in problem solving models that are carried out face-to-face because both e-learning and face-to-face learning has its advantages and disadvantages so it can complement each other. Problem-based learning can utilize schoology facilities collaboratively in problem solving. The problem solving skills of students is very important for the success of chemistry learning. If students are actively involved 
in the learning process, and problem solving skills are also honed, then the problem solving learning model is assisted by schoology. Learning steps with problem solving models require students to have a strong concept of chemistry. The concept is used as a basis for problem solving activities.

Based on the results of the research that is in line and findings in this study, it can be concluded that the problem solving learning model assisted by schoology can improve problem solving skills in learning chemistry, especially the novelty and solubility results.

\section{3) Relationship Between Cognitive Learning and Problem} Solving Skill

The students' cognitive learning outcome is believed to influence the students' problem solving skills. It can be seen that the student who reached the highest score in class having problem solving skills have developed very well (score 91.11). Seen from the cognitive learning, She is in very good/optimal level (score 100) and has reached SKBM (minimum standard of learning mastery). Based on the analytic data from Schoology the total time, of course, is 2:00:37 with 15 number of post. It is seen from the student with the lowest score having already developed problem solving skills (40.00). Seen from the cognitive learning, She is in less level (score 60) and has not reached SKBM. Based on the analytic data from Schoology the total time, of course, is 11:48 with 4 number of post in the discussion at Schoology.

The knowledge has a large and strategic impact on problem solving skills. It implies that the knowledge that has been possessed by someone will help a lot in the whole process of problem solving at every step [37]. In problem solving, students are allowed to gain experience using their knowledge and skills to solve non-routine problems, which is more directed to process problems. Thus, the knowledge possessed by students relates to problem solving abilities. Experience and knowledge formed through problem solving assisted learning models with Schoology have an impact on students' problem solving abilities [32]. Furthermore, schoology can improve the learning outcomes of students' knowledge because it is easily accessible; students have a target value, understand the lesson better, and are more active during the lesson so that it has an impact on the learning outcomes of learners' knowledge [38].

Based on calculations by the product moment correlation, there is a positive correlation between cognitive learning outcomes and problem solving skills. The obtained value is 0.908 that indicates a very strong correlation.

Based on observations and discussion, the findings obtained are:

- Problem solving learning model through Schoology can improve students' learning to develop skills such as problem solving skills of understanding the problem, devising a plan, carrying out the plan, and looking back in solving the problems.

- Problem solving learning model through Schoology can facilitate students because the material to be delivered has been given before learning in class so that students who have learned the material given will be easier to follow the learning and the learners still can re-read material that they still do not understand.

\section{CONCLUSION AND RECOMMENDATION}

Based on the results and discussion of the study, it is concluded that: (1) There is a significant difference in cognitive learning outcomes between the students who learn the material of solubility and constant solubility product using Problem solving learning model through Schoology in the learning activities and those who learn the material of solubility and constant solubility product using Problem Solving Polya model. (2) There are significant differences in problem solving skills between the students who learn the material of solubility and constant solubility product using Problem solving learning model through Schoology in the learning activities and those who learn the material of solubility and constant solubility product using Problem Solving Polya model.

The suggestions given are:

- The teachers, especially chemistry teachers, can consider implementing the problem learning a solvingschoology model to develop problem solving skills and to optimize students' learning outcomes. Furthermore, this learning model can also be applied to overcome the lack of time allocation by face-to-face learning.

- It is suggested to prospective researchers to conduct a study using other webs more optimally to be able to study the problem solving skills and learning outcomes of students in addition to those that have been used in this study.

\section{REFERENCES}

[1] R. Rusman, Model-model pembelajaran: Mengembangkan profesionalisme guru, edisi Kedua, Jakarta: Rajawali Press, 2014.

[2] O. de Jong and K. S. Taber, The many faces of high school chemistry, New York: Routledge, 2014.

[3] J. Bennett and S. Hogarth, "Would you want to talk to a scientist at a party? High school students' attitude to school science and to science," International Journal of Science Education, vol. 31, no. 14, pp. 19751998,2009

[4] J. Osborne and J. Dillon, "Science education in Europe: Critical reflections," London: King's College, 2008.

[5] OECD, "PISA 2012 results in focus: What 15-year-olds know and what they can do with what they know," 2014.

[6] OECD, "PISA 2015 Results in Focus," 2016.

[7] P. E. Childs and M. Sheehan, "What's difficult about chemistry? An irish perspective," Chemistry Education Research and Practice, vol. 10, no. 3, pp. 204-218, 2009.

[8] W. Gräber, "German high school students' interest in chemistry: A comparison between 1990 and 2008," Education Quimica, vol. 22, no. 2, pp. 134-140, 2011.

[9] BSNP, “Aplikasi Pamer UN 2016,” Jakarta: BSNP, 2016.

[10] E. Cook, E. Kennedy and S. Y. McGuire, "Effect of teaching metacognitive learning outcomes strategies on performance in general chemistry courses," Journal of Chemical Education, vol. 90, no. 8, pp. 961-967, 2013.

[11] D. P. Cartrette and P. M. Mayo, "Students' understanding of acids/bases in organic chemistry contexts," Chemistry Education Research and Practice, vol. 12, no. 1, pp. 29-39, 2011.

[12] S. Pusporini, Ashadi and Sarwanto, "Pembelajaran kimia berbasis problem solving menggunakan laboratorium riil dan virtuil ditinjau dari 
gaya belajar dan kemampuan berpikir kritis peserta didik," Jurnal Inkuiri, 2012

[13] C. Chin and D. E. Brown, "Student-generated questions: A meaningful aspect of learning science," International Journal of Science Education, vol. 24, no. 5, pp. 521-549, 2002.

[14] G. M. Bodner and D. S. Domin, "Mental models: The role of representations in problem solving in chemistry," University Chemistry Education, vol. 4, no. 1, pp. 24-30, 2000.

[15] P. Black, R. McCornock, M. James and D. Pedder, "Learning how to learn and assessment for learning: A theoretical inquiry," Research Papers in Education, vol. 21, no. 2, pp. 119-132, 2006.

[16] G. Polya, How to solve it: A new aspect of mathematical method, New Jersey: Princeton University Press, 1973.

[17] N. Jalinus and Ambiyar, Media \& sumber pembelajaran, Jakarta: Kencana, 2016.

[18] T. Gok and I. Silay, "The effects of problem solving strategies on students' achievement, attitude and motivation," Eurasian Journal of Physics and Chemistry Education, vol. 4, no. 1, pp. 7-21, 2010.

[19] T. Aminoto and H. Pathoni , "Penerapan media e-Learning berbasis schoology untuk meningkatkan aktivitas dan hasil belajar materi usaha dan energi di kelas XI SMA N 10 Kota Jambi,” Jurnal Sainmatika, vol. 8, no. 1, pp. 13-29, 2014.

[20] H. T. Y. Ju, N. Mai and B. Selvaretnam, "Enhancing problem-solving skills in an authentic blended learning environment: A Malaysian context," International Journal of Information and Education Technology, vol. 5, no. 11, pp. 401-420, 2015.

[21] S. Sugiyono, Metode penelitian pendidikan: Pendekatan kuantitatif, kualitatif, dan R\&D, Bandung: Penerbit Alfabeta, 2016.

[22] Cohen and Swerdlik, Psychology testing and assessment: An introduction to test and measurement, New York: McGraw-Hill, 2010.

[23] U. Sekaran, Research methods for business: A skill-building approach, Singapore: John Wiley \& Sons, Inc, 2000.

[24] R. R. Hake, Analyzing gain/gain scores, California: Indiana University, 1999.

[25] M. V. L. Perez, M. C. P. Lopez and L. R. Ariza, "Blended learning in higher education: Students' perceptions and their relation to outcomes," Computer and Education, pp. 818-826, 2011
[26] J. A. Durlak, R. P. Weissberg and M. Pachan, "A meta-analysis of afterschool programs that seek to promote personal and social skills in children and adolescents," American Journal of Community Psychology, vol. 65, pp. 294-309, 2010.

[27] A. Ebrahim, "The effect of cooperative learning strategies on elementary students' science achievement and social skills in Kuwait. Internationa Journal of Science and Mathematics Education," Vol.10, 293-314, 2012.

[28] E. Siregar and H. Nara, Teori belajar dan pembelajaran, Bogor: Penerbit Ghalia Indonesia, 2014

[29] S. Biswas, "Schoology-supported classroom management: A curriculum review," Northwest Journal of Teacher Education, vol. 11, no. 2, 2013.

[30] V. Arkoful and N. Abaidoo, "The role of e-Learning, the advantages and disadvantages of its adoption in higher education," International Journal of Education and Research, vol. 2, no. 12, pp. 397-410, 2014.

[31] G. J. Hwang and F. R. Kuo, "A structural equation to analyse the antecedents to students' web-based problem-solving performance," Australian Journal of Educational Technology, vol. 31, no. 4, pp. 400420, 2015.

[32] D. J. Priansa, Pengembangan strategi \& model pembelajaran inovatif, kreatif, dan prestatif dalam memahami peserta didik, Bandung: Penerbit Pustaka Setia, 2017.

[33] I. Marcut, "Critical thinking: applied to the methodology of teaching mathematics," Educatia Matematica, vol. 1, no. 1, pp. 57-66, 2005.

[34] A. Zaif, Sunardi and N. Diah, "Penerapan pembelajaran pemecahan masalah model polya untuk menyelesaikan soal-soal pemecahan masalah pada siswa kelas IX I SMP Negei 1 Jember semester ganjil tahun ajaran 2012/2013," Pancaran, vol. 2, pp. 119-132, 2013.

[35] N. R. Yanti and Syahmani, "Implementasi model problem based learning berbantuan tes superitem terhadap kemampuan pemecahan masalah materi kelarutan dan hasil kali kelarutan," Jurnal Inovasi Pendidikan Sains, vol. 7, no. 2, pp. 147-155, 2016.

[36] G. Pluck and H. Johnson, "Stimulating curiosity to enhance learning," GESJ: Education Science and Psychology, vol. 2, no. 19, pp. 24-31, 2011.

[37] M. Surya, Strategi kognitif dalam proses pembelajaran, Bandung: Penerbit Alfabeta, 2015.

[38] A. Efendi, "E-learning berbasis schoology dan edmodo: Ditinjau dari motivasi dan hasil belajar siswa SMK," Elinvo (Electronics, Informatics, and Vocational Education), vol. 2, no. 1, pp. 50-58, 2017 